\title{
0 Projeto Manejo \\ Ecológico e Exploração \\ da Floresta Tropical Úmida
}

Os trabalhos iniciais para a implantação deste Projeto retroagem ao ano de 1977, tendo suas diretrizes finais em maio de 1978, quando tivemos no INPA, durante um encontro do Programa do Trópico Úmido, simultaneamente, as visitas dos Presidentes do CNPq e da FINEP. Nesta reunião, foram finalmente definidas as linhas de pesquisas mais importantes, graças ao posicionamento adotado pelos amigos Antonio Dantas Machado (CNPq), Reinaldo de Jesus Araújo (FINEP) e Warwick Estevam Kerr (INPA). A data de 16 de outubro de 1978 marcou a assinatura dos convênios 530/CT e 531/CT e o início dos repasses dos recursos do BID (Banco Interamericano de Desenvolvimento) e do FNDCT (Fundo Nacional de Desenvolvimento Científico e Tecnológico), por intermédio da FINEP.

Nos últimos seis meses, no entanto, foi necessário refazer inteiramente, por exigências do órgão financiador, os detalhes do Projeto, dentro das linhas de ação traçadas originalmente. Assim é que, após estudos detalhados e reuniōes de representantes dos órgãos interessados, finalmente o Projeto entrou em sua fase operacional em outubro de 1979.

Apesar dos doze meses perdidos e de outros contratempos, a satisfação dos pesquisadores envolvidos é muito grande, pois, a julgar por alguns dos colaboradores mais antigos, este Projeto traz o INPA de volta às origens.

O Projeto subdivide-se em duas linhas mestras que são Exploração e Manejo Florestal e Utilização e Tecnologia de Produtos Florestais a serem desenvolvidos em área experimental situada à margem da estrada Vicinal ZF-2 da SUFRAMA, distando $20 \mathrm{~km}$ da Rodovia BR-174, Manaus-Caracaraí, dentro do Distrito Agropecuário da Zona Franca de Manaus, a $60 \mathrm{~km}$ desta Cidade, definida por uma bacia hidrográfica com cerca de 1.730 hectares, constituída de vários igarapés afluentes do Tarumãzinho. A área dispõe de acesso viário normal garantido o ano todo, localizada a apenas $20 \mathrm{~km}$ da Estação Experimental de Silvicultura Tropical do INPA, e ao lado de outra bacia hidrográfica, de tamanho semelhante, sob proteção total, sem manejo, na qual o INPA, SUDAM (Projeto BRA/72/010) e CENA já estudam a dinâmica da população de árvores, ciclo da matéria orgânica, ciclo hidrológico e de nutrientes minerais, qualidade de água dos igarapés, ecologia e etologia de vertebrados, entomologia florestal, capacidade de suporte, reconstituição vegetal após derrubada, distribuição de raízes, etc. O Projeto prevê ainda o desenvolvimento de linhas intimamente selecionadas com a Exploração e Manejo Florestal, tais como: levantamento florístico, fisiologia vegetal, manejo dos recursos hídricos, malária, leishmaniose, outros focos naturais de doenças tropicais. produtos florestais secundários, etc. 
Os recursos envolvidos no Projeto são da ordem de Cr\$ $190 \mathrm{mi}$ Ihões, alocados do Fundo Nacional de Desenvolvimento Científico e Tecnológico - FNDCT e USS 5,5 milhões garantidos pelo Banco Interamericano de Desenvolvimento - BID, tendo como órgão repassador do montante total a Financiadora de Estudos e Projetos - FINEP. A soma em dólares americanos permitirá a aquisição de equipamentos de pesquisa, assistência técnica ao Projeto e treinamento de pessoal no exterior, enquanto que a contrapartida brasileira possibilitará a contratação de 110 pessoas entre pesquisadores pós-graduados, engenheiros, técnicos agrícolas, práticos de campo, trabalhadores rurais, etc.; a construção dos laboratórios do Centro de Tecnologia de Madeira, localizado no Campus do INPA, com cerca de $3.000 \mathrm{~m}^{2}$ de área construída, do Prédio da Botânica e Herbário do Museu Paraense Emílio Goeldi, no núcleo do Guamá, em Belém, com cerca de $1.000 \mathrm{~m}^{2}$ de área construída e o Prédio da Ecologia e Silvicultura, na estrada do V-8, com $2.000 \mathrm{~m}^{2}$, onde se encontra localizada a Divisão de Agronomia do INPA, a cerca de $600 \mathrm{~m}$ do Campus do INPA, no Aleixo e ainda despesas de custeio relacionadas diretamente com o Projeto.

Dos recursos garantidos pelo BID, possuímos listas de equipamentos de pesquisa importados, devidamente aprovados pela Diretoria do CNPq, da ordem de USS 2,6 milhões, sendo que este valor se estenderá até meados de 1980 a US\$ 3,5 milhões. Relação referente a cerca de US $\$ 500$ mil já se encontram na FINEP para emissão de carta de crédito, significando, com isto, o recebimento dos primeiros equipamentos a partir de janeiro próximo. Com relação à assistência técnica aos subprojetos principais, o CNPq/INPA, firmou contrato em sistema "cost sharing", com a FAO, através do PNUD, para receber 3 especialistas nas áreas de Silvicultura, Manejo Florestal e Tecnologia da Madeira Os recursos destinados à assistência técnica prevêem ainda a vinda de vários outros técnicos para dar um valioso suporte a outras áreas de pesquisa intimamente ligadas ao escopo principal do Projeto, assim como, para participarem do treinamento do pessoal local possibilitando a formação de mão-de-obra qualificada para qualquer trabalho silvicultural na região. O treinamento de pessoal do INPA, ou mesmo, de engenheiros recém-contratados, inicia-se em janeiro em alguns centros de pesquisa do país e, posteriormente, em diversas instituiçōes estrangeiras.

Com relação ao subprojeto Exploração e Manejo Florestal todos os tratamentos florestais, exploração e silvicultura serão localizados na bacia hidrográfica selecionada, que então, poderá ser comparada com a bacia hidrográfica não manejada vizinha. Este é um trabalho nunca antes realizado no País e que terá o maior significado se considerarmos que as informaçōes científicas no campo do manejo florestal são insuficientes para uma afirmação definitiva sobre o método meIhor a ser adotado, mas que a princípio, nos mostra de modo claro, o frágil equilíbrio ecológico da região. Se a floresta representa este equilíbrio e continua a ser cortada como se vem processando, serão graves os problemas com erosão e perda de solos, já sabidos de baixa 
fertilidade e, em conseqüência, a exuberância da floresta que é resultado da reciclagem contínua de nutrientes, poderá ser eliminada e desta forma provocar sérios problemas ecológicos.

A implantação do Centro de Tecnologia da Madeira - ação principal do subprojeto Utilização e Tecnologia de Produtos Florestais vem ao encontro dos reclamos do meio empresarial da região se atentarmos para o fato de que o aproveitamento industrial desta matériaprima é insignificante, sem nenhuma integração, acarretando desperdício considerável. A possibilidade da utilização da maioria das madeiras da região, tem sido questionada, decorrente de inúmeros fatores, entre os quais a falta de melhores e maiores conhecimentos que possibilitem avaliar as características e a qualidade das madeiras da região e que viabilizem o seu aproveitamento. Em decorrência disso, o número de espécies de madeira da Amazônia que são beneficiadas industrialmente é muito reduzido, situando-se em torno de 30 espécies.

Por último deve ressaltar-se ainda, o início da instalação do Laboratório Central de Análises Químicas, sob o patrocínio deste Proịeto, que prevê o fornecimento de serviços a toda a Comunidade Científica do INPA e de outras instituições da região. Desta forma, a análise de solos, proteínas, vitaminas, óleos vegetais, óleos essenciais, gordura animal, elementos minerais da água, taninos, corantes, exudatos vegetais, resinas, etc., serão realizadas por técnicos treinados, utilizando equipamentos científicos atualizados.

José Guilherme S. Maia

Coordenador Científico do Projeto 